the creation of special buildings at St. Andrews, and that further expansion could still be undertaken at Queen's College, Dundee, was upheld by the Commissioner. Although criticized by the Professor of Physics as shortsighted, this view was supported by the University Grants Committee.

\section{The Commonwealth Trans-Antarctic Expedition}

Tre tractor train of the New Zealand Antarctic expedition led by Sir Edmund Hillary reached the South Pole on the night of January 3. This is the first time that the Pole has been reached overland since the pioneer expeditions of Amundsen and Scott. The expedition, which also includes P. Mulgrew, M. Ellis, J. Bates and D. Wright, reached the American base at the Pole having driven three tractors, two sledges and a caboose 1,200 miles from Scott Base since October 14. The New Zealand expedition, in conjunction with a R.N.Z.A.F. party under SquadronLeader J. Claydon flying a Beaver aircraft, has laid down five depots of food and fuel between Scott Base and Depot 700, about seven degrees of latitude short of the Pole, in support of the United Kingdom trans-Antarctic survey party under Dr. Vivian Fuchs, which proposes to cross the continent from the Weddell Sea to the Ross Sea. At the time of writing, Dr. Fuchs' team, about three hundred miles from the Pole, is encountering hard going from sastrugi (iceridges) impeding the progress of his tracked vehicles. On January 6 Squadron-Leader J. Lewis, flying an R.A.F. Otter single-engine aircraft, traversed the Antarctic continent from the advance British base at South Ice to Scott Base, where Dr. Trevor Hetherington's team of scientists is continuing its programme of observations for the International Geophysical Year.

\section{Soviet and Western Attitudes to Science}

THE text of a talk entitled "What is the Right Attitude to Science ?" by Dr. K. Mendelssohn, reader in physics in the University of Oxford, broadcest on December 23 on the B.B.C. Third Programme, has recently been published in The Listener (January 2, p. 12). Dr. Mendelssohn points out that science and technology, to which the West owes its high standard of living, have been taken so much for granted that they are now accorded second place in the educational system. Now, quite apart from military considerations, the prospect of Russian technological superiority may make it an economic necessity to re-assess the Western position. It is a dogma of Soviet economics that prosperity is based on technological progress, and the rewards to scientists and engineers both in salary and status in the Soviet Union are accordingly high. Even more important is the fact that science in the U.S.S.R. is administered at the highest levels by the Soviet Academy of Sciences and not by politicians or generals. The position is almost the exact opposite in the United States, where the direction of scientific effort is largely in the hands of non-scientists, which not only leads to defective decisions, but also relegates the scientist to a subordinate position. In Britain, on the other hand, while science is mostly directed by scientists, the false dichotomy between science and the humanities has created an almost hostile, or at least defensive, public feeling against science. This, together with early specialization in British schools, has tended to discourage entry into scientific professions. The Russian achievements are largely due to money spent on scientific education and research, even at times when the Soviet Union was passing through economic crises. Dr. Mendelssohn suggests that in Britain more money spent on education could still buy time : time essential for a good general training in both arts and science and for an extra year at a university.

\section{Recent Earthquakes}

ON December 4 a very great earthquake occurred in Outer Mongolia, with epicentre near latitude $45 \frac{1}{2}^{\circ} \mathrm{N}$., longitude $99 \frac{1}{2}^{\circ} \mathrm{E}$. The initial time of this shock was $03 \mathrm{~h}$. $37 \mathrm{~m}$. 45s. G.M.T., and it attained magnitude 7.9 on the Gutenberg-Richter scale. This earthquake was registered on the seismograph at the Royal Observatory, Edinburgh, with maximum ground amplitude of almost $250 \mu$. After-shocks from this and neighbouring epicentres were frequent, especially during the first half of December. Six great aftershocks occurred on December 4, four on December 8 and one each on December 5, 7 and 11 , besides numerous smaller ones. All these shocks were registered throughout the world. The area affected macroseismically included the districts of Bayankhongor, Ara Khangai and Ubur Khangai. A wide permenent fissure more than six miles long is said to have appeared in Bayan Tsagan at the time of the earthquake.

On December 13 a smaller earthquake occurred in western Persia with epicentre near latitude $341^{\circ}$ N., longitude $48^{\circ}$ E. It had magnitude $7 t$, and occurred at $01 \mathrm{lh} .44 \mathrm{~m}$. 59s. G.M.T. It was registered on the seismograph at the Royal Observatory, Edinburgh. The macroseismic effects of this shock were very great in the triangle bounded by Kermanshah, Hamadan and Sanandaj. Murdistan, Assadabad and Kangavar were severely damaged, and Farsinaj was almost destroyed. The earthquake may have caused the deaths of 2,000 people.

\section{The Griffin Gas Chromatography Apparatus}

Messrs. Griffir and George, Ltd., have isgued a very well-produced pamphlet describing the Mark 2 version of their gas chromatography apparatus. This pamphlet is profusely illustrated with diagrams and photographs, and also contains a short bibliography which will be useftrl to anyone intending to use gas chromatography for the first time. Typical chromato. grams obtained with the Griffin and George equip. ment are reproduced, and these illustrate the versatility of gas chromatography, showing the analysis of a range of compounds from the $\mathrm{C}_{8}-\mathrm{C}_{18}$ fatty acids and their esters, to a series of simple aromatic hydrocarbons. Some indication of the special virtues of a number of different stationary phases is given in a short table.

\section{Zoological Nomenclature}

THE International Trust for Zoological Nomenclature has arranged for the publication in book form of the first instalment of each of the "Official Lists" of valid zoological names and of the corresponding "Official Indexes" of rejected and invalid names, together with the first instalment of the "Official Lists" of work approved as available for zoological nomenclature and of the "Official Index" of rejected and invalid works. The categories of names covered by these lists and indexes range from specific names to ordinal names, and the total number of entries now to be published is about five thousand. The first of these lists, relating to generic names, was 